\title{
How to Promote the Geopark Ciletuh-Palabuhanratu as A Tourist Destination Area
}

\author{
Yuli Diani Rahmawati ${ }^{1, *}$ Ratih Hurriyati ${ }^{2,}$ Nandi $^{3}$
}

\author{
${ }^{1}$ Universitas Pendidikan Indonesia \\ ${ }^{2}$ Universitas Pendidikan Indonesia \\ ${ }^{3}$ Universitas Pendidikan Indonesia \\ *Corresponding author.Email: dianiyuli@gmail.com
}

\begin{abstract}
The Geopark Ciletuh-Palabuhanratu Attractiveness is one of the tourist attractions in Sukabumi Regency, West Java, Indonesia. It is coming in the form of varied tourist attractions; the location is also served a complete tour in Java and offers expanse views coral reefs and some beautiful mountain waterfalls. In this area, visitors can enjoy the natural scenery offered. It starts from the mountains, waterfalls, beaches, peaks, and beautiful landscaping with a sea background. The number of tourists visiting the area attraction continues to increase from year to year, this is because it has been recognized as a world heritage by UNESCO GLOBAL GEOPARK, but the increase is not following the target expected by the management. This study aims to look at the management's promotion strategy to increase the number of tourists visiting the Geopark Ciletuh-Palabuhanratu. The method used in this research was descriptive with data analysis techniques through in-depth literature and documentation studies. This study's results are promotional strategies that have been applied in increasing the number of tourists visiting the Geopark Ciletuh-Palabuhanratu by using a promotional mix of advertising, personal selling, direct marketing, public relations, and sales promotion. This research shows that a mix of tourism marketing communication strategies contributed towards broader information dissemination and bridging cooperation benefiting Geopark Ciletuh as a tourist destination area.
\end{abstract}

Keywords: geopark ciletuh-palabuhan rat, marketing mix, natural landscape, promotional mix, tourism, tourist destination area.

\section{INTRODUCTION}

Tourism in Indonesia is very instrumental in national development because this sector is an activity that directly touches and engages the community to bring benefits and positive impacts for the surrounding community [1]. Tourism can increase foreign exchange income in particular and the income of the state and society in general, expand employment opportunities, and encourage the activities of supporting industries and other side industries, introducing and utilizing Indonesia's natural beauty and culture [2].

Tourism is an essential sector in economic development because tourism is very closely related to all economic sectors, and therefore this sector makes many significant contributions to the economy of a region [3]. Competition in the world of tourism results in the management of tourist attractions must carry out an integrated promotion strategy to increase and maintain tourist visits[4].

In general, strategic issues in tourism development in Sukabumi Regency as the local government in the Geopark Ciletuh-Palabuhanratu (GCP) region includes: the rapid development of tourism in other regions; inadequate quality and availability of infrastructure [5], low level of community service to tourists; the existence of street vendors around attractions that have not been arranged and managed well so that the impression of slums; the quality of tourism human resources is still low; tourism partnership not yet optimal; not yet optimal tourism industry that can support the 
development of regional tourism destinations [6] and tourism promotion is not optimal.

A strategy in marketing is needed to answer this challenge by conducting an appropriate promotion to attract the number of tourist visits following the expected target [7]. A good promotion strategy will produce a planned strategy implemented under government programs [8].

Promotion strategies are carried out using a promotion mix consisting of advertising, personal selling, direct marketing, public relations, and sales promotion. It is combined with a marketing mix consisting of $7 \mathrm{P}$, namely product, price, place, promotion, people, process, and physical evidence [9]. The use of both promotional mix strategy and marketing mix, separately, generally pointing out that direct sales had a more significant impact on tourist destination performance beyond promotion [10], [11]. Both strategies are objected to management's ability to increase tourist visitors' number to the GCP Tourist Destination Area. However, the increase of visitors should be following the carrying capacity of the geopark itself [12]. Therefore, this research is carried to see how the GCP Tourist Destination Area promotion could be significantly conducted by implementing a mix of tourism marketing communication that consists of a promotional mix and marketing mix strategy.

\section{METHODS}

This research was conducted at the Geopark CiletuhPalabuhan ratu (GCP) Tourism destination in Sukabumi Regency, West Java Province. Qualitative research has several methods commonly used in social science research, qualitative research in phenomenology. This study specializes in phenomena and realities that seem to study the explanations in them, explore data to find meaning from the primary and essential things of phenomena, reality, or experience experienced by the research object [13]. How to collect data through descriptive analysis with a survey approach, literature study, and documentation study.

The method used in this research is descriptive analysis. Data was obtained from the local government, the Head of the Tourism office, and the local community. Data analysis techniques through in-depth literature studies and documentation studies.

The research scope used was a promotional strategy using a promotion mix [9] consisting of 1) advertising, 2) sales promotion, 3) personal selling, 4) direct marketing, 5) public relations, and combined with marketing mix (marketing mix) which consists of 7Ps, namely product, price, promotion, location, place, people, process, physical evidence to increase the number of tourists to the Ciletuh-Palabuhanratu Geopark.

\section{RESULTS AND DISCUSSION}

\subsection{Profile of Geopark Ciletuh-Palabuhanratu}

The profile of GCP can be seen from the geological point of view. The Ciletuh Geological Region is unique and very interesting to study because its geology is the result of the collision of two different plates, namely the Eurasian Plate (continental plate), which is composed of granite (acid), and the Indo-Australian Plate (oceanic plate) which is composed of basal (base), produce deepsea sedimentary rocks (pelagic sediment), metamorphic rocks (altered rocks), and igneous rocks to ultra-base bases. What is unique about the Pre-Tertiary rock outcrop in the Ciletuh area is that all of the rock outcrops are located in a large valley resembling an amphitheater in the shape of a horseshoe that opens towards the Indian Ocean [5].

Ciletuh area has the potential for geological uniqueness that can be developed as a complete tourist destination with comparative and competitive advantages [14]. This region has a very different and varied natural potential that many other regions do not share in Indonesia. The advantage lies in its extraordinary natural beauty, the combination of coastal and hilly landscapes, waterfalls, and unique geological rocks, and the diversity of flora and fauna that are difficult to find in other regions. Not exces-sive if this area is dubbed as the outskirts of heaven in West Java [15]. The location of geopark ciletuh-palabuhanratu area show by fig. 1

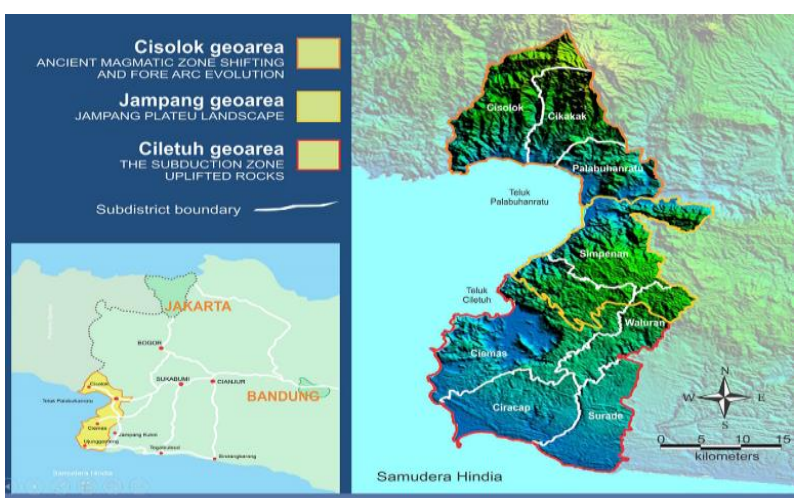

Figure 1. The location of Geopark Ciletuh-

Palabuhanratu Area

\subsection{Geopark Ciletuh-Palabuhanratu promotion strategies}

Type Promotion Strategy Applied in Increasing the Number of Tourist Visits to the GCP Tourism Attraction. To introduce and bring visitors to GCP Tourism, management needs to carry out various promotion forms, so that prospective visitors first know and know about GCP tourism. The form of promotion carried out by managers is based on five promotional mixes or marketing communication mix: advertising, personal 
selling, direct marketing, public relations, and sales promotion [9].

\subsubsection{Advertising}

Any paid form of non-personal presentation and promotion of ideas, goods, or services by a particular sponsor is advertising [17]. Reference [18], there is no statistically significant proving of an advertisement on awareness, credibility, or purchase intents. However, Lord and Putrevu [19] reported that advertising had received considerable conceptual and empirical attention based on its literature. One of the promotional mixes done by the GCP Tourism management is Advertising. The form of advertising is done by making brochures regularly, making brochures in the form of advertising that is always and must be done as a promotional medium [20]. Brochures that the management has made are distributed at public facilities such as terminals, air-ports, and stations [21]. Besides, brochures were also circulated to various lodgings such as hotels in the vicinity of Pelabuhan ratu. Collaborating with several traveling applications was also one form of advertising promotion conducted by the management. This is done to facilitate prospective visitors to access information about lodging and accommodation for GCP Tourism. One of the applications is Traveloka. The application is also connected by residents' homes used as lodgings or commonly referred to as homestays. In addition to the brochure, which is a print media, the GCP Tourism management also advertises the GCP in various Travel Magazines on several airlines. This is one form of advertising promotion whose scope is broader than the two previous advertising promotion forms because the target form of advertising in Flight Travel Magazine can reach people outside of Java, even International.

\subsubsection{Personal selling}

Communicating the product directly (face-to-face) and verbally to potential buyers to provide the product, service, or information and responding to requests or others is referred to as personal Selling [22]. Personal selling is also a promotional mix that could be measured through activities, such as training and skills level of sales staffs, style, and appearance, capabilities in providing information to solve problems, product or service display, verbal persuasion, presentation, etc. [23]. In Geopark Ciletuh-Palabuhanratu, personal selling is carried out periodically by the tourism management. One way is to hold or attend a tourism exhibition. For example, last year, GCP has attended an exhibition or UNESCO activity in Italy, and at that event, GCP opened a stand as a form of promotion. Opening travel booths in places such as stations, airports, terminals also become a form of personal selling. Besides, there are often collaborations between prominent figures such as the Governor of West Java, who upload GCP promotional videos on his personal Instagram account, with digital, of course, the scope of promotion is much more comprehensive. Nour reported that the importance of personal selling is in the second position after advertising and above sales promotion [24].

\subsubsection{Direct marketing}

Direct marketing is the process of communicating or collect responses from specific customers and prospects through non-personal contact tools, such as mail, telephone, or others. [25]. In adopting integrated marketing communication, direct marketing is seen as a tactical way [26]. Practices done by GCP management on implementing direct marketing are developed under the official website obliged for the GCP tourism manager. Because according to them, in the current digital era, all forms of promotions carried out in digital form will be much easier to access.

Furthermore, having an official website will make it easier for prospective visitors to obtain information. Moreover, the information obtained is more credible because it is an official website managed by GCP directly. On the official website, there is also an email address information if potential visitors want to find out more detailed information. Besides, a call center service can also help the public ask questions about GCP Tourism. In addition to going through the official website, the GCP Tourism Management also uploads photos and videos regularly to Instagram and Facebook accounts to show the beauty of the GCP Tourism objects to the public through photos and videos.

\subsubsection{Public relations}

Public Relations is an integral part of a company and is a form of promotion that is equally important [27]. Public relations emphasizes a good relationship developed between the organization and its audience to achieve satisfaction and mutual understanding, internally or externally, by implementing policies and programs based on social responsibility and utilizing media to build the organization's right image [28]. In the GCP Tourism, Public Relations are often a part that connects tourism with outsiders. One form of Public Relations that is carried out is by inviting the media or holding press releases related to the big moments that occur at GCP, for example, when the GCP was set to be part of UNESCO in 2017. With the momentum occurring around the GCP Tourism, the management will write all the latest activities and upload them to the official website to always be up to date. Another form of public relations is to support Television Programs that want to cover attractions in the GCP because this can also be advantageous for GCP Tourism. Some examples 
of Television Programs are "My Trip My Adventure" and "The Beautiful Adventurers," as well as Online Media or News that want to raise the GCP as their news feature material. Of course, the GCP management will be very open to the media who indirectly promote GCP Tourism. Participating in several events such as travel fairs is also a form of public relations conducted by the GCP. Because for now, there is often a large travel fair event which is also attended by several companies and various tours in Indonesia. Travel fairs are also often attended by several airlines in Indonesia. At that moment became an opportunity to participate in opening a booth because it will be attended by many people who are aiming to travel and seek tourism information.

\subsubsection{Sales promotion}

Sales Promotion, conducted in particular times, aimed to stimulate increased demand or prove the product availability [29]. Optimum sales promotion effort is carried to maximize customer satisfaction of their wishes and needs comparatively with other competitor commodities [23]. Sales promotion conducted by the GCP management is to provide tour packages with lodging in the homes of residents with a variety of different classifications, commonly called homestays. In addition to residents' homeowners, the GCP management also cooperates with the natureloving community in Ciletuh to manage tourists' activities, commonly called open trips and asks residents to introduce the GCP tourism to tourists come. In addi-tion to lodging facilities, the manager also cooperates with the citizens in terms of transportation so that resi-dents come to provide transportation facilities needed for tourists. All forms of sales promotion carried out by the GCP management benefit both parties, such as residents who can also earn income from renting homes and transportation. On the other hand, it is also an advantage for managers to guarantee accommodation for tourists.

\section{CONCLUSION}

The Geopark Ciletuh-Palabuhanratu (GCP) area has officially become part of the UNESCO global geopark. The promotion strategy were using a mix of tourism marketing communication, which consists of (1) advertising, where brochures have been made and advertisements placed in a flight magazine; (2) private sales, which are organizing exhibitions by management at various events and also opening travel booths at places such as stations, airports and or terminals; (3) Direct marketing, has been done through creating pages, making pages on various social media, uploading photos and videos related to tourism activities and news about the area and information related to activities that will be carried out; (4) Public relations has been carried out in the form of activities to invite television media, making this area a location for shooting advertisements, films or media promoting company products and participating in exhibitions at various events; (5) Marketing promotion, carried out by making several tour packages offered to visitors, in addition to providing tourism facilities and accommodation to support tourism activities, has also been carried out through cooperation with travel agents, the media and the local government.

\section{ACKNOWLEDGMENT}

Contribution toward this research is provided by Geopark-Ciletuh Palabuhanratu (GCP) upon the availability of data and information needed regarding the GCP tourist destination area promotion.

\section{REFERENCES}

[1] Kementrian Pariwisata 2018, "Travel \& tourism economic impact 2018 Indonesia," Kementrian Pariwisata, 2018.

[2] J. de Haan, "The Indonesian tourism industry: a bright future and opportunities for Australia," no. March 2018, p. 10, 2018.

[3] L. U. Xhiliola Agaraj, "Turismul - un sector important în dezvoltarea economică," no. 1, pp. 8390, 2009.

[4] F. Kerem, "Competition strategies for tourism industry in the context of sustainable development competition strategies for tourism industry in the context of sustainable development," 2nd Int. Symp. Sustain. Dev., no. June 2010, pp. 587-597, 2016.

[5] Y. Yanuar, Z. Anna, M. F. Rosana, A. Rizal, A. Sudrajat, and Z. Zakaria, "Sustainable development of geopark national ciletuh-palabuhanratu in the infrastructure perspective," J. Sosek Pekerj. Umum, 2018.

[6] A. Ilfandy and D. K. Soedarsono, "Sustainable development communication for supporting tourism at the area surrounding unesco global geopark ( ugg ) of Palabuhanratu," 5th Conf. Commun. Cult Media Stud., no. April 2019, pp. 14-16, 2019.

[7] L. S. Mwaawaaru, "Marketing strategy in terms of promotion and communication for energy drinks in ghana: case company," Bus. Econ. Tour., 2009.

[8] R. Tsiotsou, "Introduction to strategic marketing in tourism," Emerald Group Publishing Limited, 2012.

[9] P. Kotler and K. L. Keller, "Manajemen pemasaran Jilid 1," 2009.

[10]R. Masa'deh, O. Alananzeh, A. Tarhini, and O. Algudah, "The effect of promotional mix on hotel performance during the political crisis in the Middle East,” J. Hosp. Tour. Technol., 2018.

[11]B. Sulistyadi, N. Wening, and T. Herawan, "The Effects of promotion and site attraction on satisfaction and subsequent impact on loyalty: a 
case study in Gunung Sewu Unesco Global Geopark, Indonesia,” J. Tour. Manag. Res., 2019.

[12] W. Guo and S. Chung, "Using tourism carrying capacity to strengthen unesco global geopark management in Hong Kong," Geoheritage, 2019.

[13] B. E. Neubauer, C. T. Witkop, and L. Varpio, "How phenomenology can help us learn from the experiences of others," Perspect. Med. Educ., 2019.

[14] Y. M. Nandi, "Visual landscape analysis of coastal tourism potential in Geopark Ciletuh-Palabuhanratu Indonesia," Sci. Bull. Nav. Acad., vol. XXII, pp. 46-52, 2019.

[15] S. Sarah Andriany, M. Rosana Fatimah, and A. Hardiyono, "Geowisata Geopark Ciletuh: Geotrek mengelilingi keindahan mega amfiteater ciletuh (the magical of ciletuh amphitheater)," Bull. Sci. Contrib., vol. 14, no. 1, pp. 75-88, 2016.

[16] S. Sarah Andriany, M. Rosana Fatimah, and A. Hardiyono, "Geowisata Geopark Ciletuh: Geotrek Mengelilingi Keindahan Mega Amfiteater Ciletuh (the Magical of Ciletuh Amphitheater)," Bull. Sci. Contrib., 2016.

[17]P. Kotler, "Marketing management: analysis planning implementation and control," J. Retail., 1994.

[18]D. W. Stacks and D. Michaelson, "Exploring the comparative communications effectiveness of advertising and public relations: a replication and extension of prior experiments Don W. Stacks and David Michaelson,” Public Relat. J., 2009.

[19]K. R. Lord and S. Putrevu, "Advertising and publicity: An information processing perspective," J. Econ. Psychol., 1993.
[20] S. Durianto, A. W. Widjaja, and H. Supratikno, "Inovasi pasar dengan iklan yang efektif," Jakarta: Erlangga, 2003.

[21]B. E. Wicks and M. A. Schuett, "Examining the role of tourism promotion through the use of brochures," Tour. Manag., 1991.

[22] J. McCarthy J. \& W. D. Perreault, Basic Marketing, 5th editio. Burr Ridge, 2004.

[23] M. I. Nour, mohammad S. Almahirah, and S. M. Said, "The impact of promotional mix elements on consumer purchasing decisions," Int. Bus. Manag., 2014.

[24][24] S. F. Mahmud I. Nour, Mohammad Salamh Almahirah, Sultan Mohammed Said, "The Impact of Promotional Mix Elements on Consumers Purchasing Decisions,” Int. Bus. Manag., 2014.

[25]J. Rowley, "Promotion and marketing communications in the information marketplace," Libr. Rev., 1998.

[26] B. Hartley and D. Pickton, "Integrated marketing communications requires a new way of thinking," J. Mark. Commun., 1999.

[27]R. Kriyantono, Public relations writing: teknik produksi media public relations dan publisitas korporat. Jakarta Indonesia: Kencana, 2008.

[28] C. Lovelock, P. Patterson, and J. Wirtz, "Services Marketing, 6th Editio,” Aust. Pearson Aust., 2014.

[29] M. I. Obydat, Consumer behavior, behavioral entrance, Fourth Edi. Amman, Jordan, 2004 